\title{
The International Labor Organization
}

\section{An American View}

\section{WALTER GALENSON}

In 1980, the United States rejoined a major United Nations agency - the International Labor Organization (ILO) - from which it had withdrawn in protest in 1977. When the U.S. formally withdrew from the ILO, it charged that the agency had become embroiled in politics. Other UN agencies have suffered from the same malaise, however, without provoking U.S. withdrawal. Why did the U.S. take such drastic action in the case of the ILO? Why has the U.S. perceived conditions as having changed sufficiently to warrant its rejoining? What is the value of this organization to the U.S., which supports a quarter of its cost of operation?

These are some of the questions addressed by Walter Galenson. He presents an insider's analysis of the problems and major functions of the ILO in a work that will appeal to scholars and students of international affairs, of U.S. foreign policymaking, of economic development, and of international labor matters, as well as to policymakers themselves and to corporate executives.

Since the major dilemmas have not been resolved, the critical question is whether the U.S. will remain a member of the ILO, and for how long. The organization will doubtless change as the balance of power in policy-making bodies shifts in favor of the less developed nations. Meanwhile, the author presents his recommendations for the proper U.S. role in ILO affairs, in order to make relationships more productive during this second phase of U.S. participation.

Walter Galenson, Professor in the School of Industrial and Labor Relations at Cornell University, is the author or co-author of nine books on international labor studies, including Trade Union Democracy in Western Europe. Over a span of two decades, he served as a consultant to both the ILO and the U.S. delegation to the ILO.

352 pages; 1981 ; cloth $\$ 21.50$; paper $\$ 7.75$

At bookstores, or write

\section{University of Wisconsin Press}

114 North Murray Street, Madison, Wisconsin 53715 
JOURNAL OF EUROPEAN INTEGRATION

\section{CONTENTS}

$$
\text { VOL.. IV, No } 1
$$

\section{Jane JENSEN}

Strategic Divisions within the French Left: The Case of the First Elections to the European Parliament

Phillip TAYLOR

Political Cooperation among the EC Member States' Embassies in Washington

\section{E.D.J. KRUIJTBOSCH}

L'expérience acquise par plus de trente ans d'integration économique dans le cadre du Benelux

Werner J. FELD and Helmut WAGNER

West Germany and European Unification: Economic and Political Interests and Policy Motivations

Naomi BLACK

Feminism and Integration: The European Communities' Surveys "European Men and Women"

Current developments - Reviews - Books received - Congresses and Seminars

The JOURNAL OF EUROPEAN INTEGRATION is published three times a year. Editorial Board - Editors: Panayotis Soldatos (Departement de science politique, Université de Montréal) Charles Pentland (Department of Political Studies, Queen's University). Members: Alex J. Easson, Faculty of Law, Queen's University, Hans J. Michelmann, Department of Economics and Political Science, University of Saskatchewan.

The Journal is a multidisciplinary publication and has as its object the promotion of the study of integration in Europe and in other regions.

Professor Panayotis Soldatos - Journal of European Integration c/o Centre d'études et de documentation européennes, Université de Montréal

C.P. 6128, Succursale "A" Montréal, Qué., Canada H3C $3 \mathrm{~J} 7$ Subscriptions: Tél. : (514) 343-7870

$\$ 18$ (Can.) per year (three issues)

$\$ 6$ (Can.) per issue. 


\section{Neue politische Literatur (NPL)}

Quarterly survey of the international literature dedicated to politics and recent history

Edited by Karl Otmar Frhr. von Aretin, Helmut Böhme, Karl Dietrich Bracher, Eugen Kogon, F. A. Krummacher, Alfred Milatz, Helmut Ridder, Hans-Gerd Schumann, Erwin Stein, Georg Strickrodt, Erwin Viefhaus

During the last 25 years comprehensive review articles were published in NPL. In recent issues the following topics, among others, were covered: Chinese Society - US-Soviet relations - Education in politics - The Weimar Crisis - German colonies in Africa Problems of Conservatism - Theory and practice of terrorism - Soviet Nationalities Eurocommunistic parties

Subscribe yourself and recommend a subscription to your librarian at DM 80 plus postage (the exchange rate varies between DM 2 to 2,50 to the dollar).

Send subscriptions to:

Franz Steiner Verlag GmbH

Auslieferung

P.O. Box 347

D-7000 Stuttgart 1

\section{Airmail Service is now available for those foreign subscribers who wish to receive their issues quickly.}

Present Second Class rates allow only surface shipment and issues often arrive 3-9 weeks after publication.

Airmail Service will insure that issues are sent First Class Air at pub. lication to arrive within a few days.

The service is $\$ 12.50 /$ year (plus the regular subscription rate) to cover postage and handling.

Regular, subscribers may request the service for their next issue; firsttime subscribers and renewals may also elect the service.

Remit in U.S. funds. Individuals must prepay. Make checks and money orders payable to: Journals, The University of Wisconsin Press.

Mail to: Journals Department

THE UNIVERSITY OF WISCONSIN PRESS

114 North Murray Street

Madison, WI 53715

Please include full information as to your name and address, your subscription status and the journal you are interested in. If possible, please send the label from the journal if you subscribe. 
Just Published . . .

\section{NORTH-SOUTH TECHNOLOGY TRANSFER: FINANCING AND INSTITUTION BUILDING}

. . . another in a growing list of valuable contributions by Jack Baranson to the field of international technology transfer. --

Eric W. Hayden

This new book is unique in its emphasis on financing the transfer of industrial technology to developing countries. It

Vice President - Economics \& Strategic Planning Bank of America presents concrete prescriptive measures for newly industrializing nations, based upon detailed country studies of industrial development and technology transfer issues in Brazil, Colombia and Mexico. 1981.160 pp. ISBN 0-91233827-X. \$15.75.

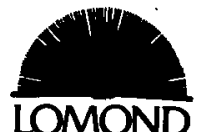

Order from:

Lomond Publications, Inc.

P.0. Box 88-10

Mt. Airy, MD 21771 U.S.A.

Also available from Lomond --

Integrated Technology Transfer by Jacques Richardson.

Theory, practice, methods and case examples for the effective use of technology in developing countries. Originally appeared in the UNESCO journal, Impact of Science on Society. 1979. 162 pp. ISBN 0912338-19-9. \$12.75.

\section{Journal of Common Market Studles Founding Editor: UWE KITZINGER Edited by LOUKAS TSOUKALIS}

Volume 19 No. 3

France, Germany, and Europe

Parliamentary accountability and the European Community

The report of the Three Wise Men

The rise and fall of Caribbean regionalisation

The practice of GATT in examining regional arrangements under article XXIV

Book reviews
CONTENTS

March 1981

Haig Simonian

David Marquand

A. N. Duff

Anthony Payne

Jürgen Huber

Annual Subscription:

Institutions: E19.50 (UK) $E 24.00$ /overseas) $\$ 49.90$ (USA) $\$ 57.00$ (Canada) Individuals: E14.00 (UK) \&17.00 (overseas) 539.50 (USA) $\$ 45.50$ (Canada) Orders to Journals Department,

108 Cowley Road, Oxford, OX4 IJF, England

Published by BASIL BLACKWELL Oxford England 


\section{DUTIES BEYOND BORDERS}

On the Limits and Possibilities of Ethical International Politics

Stanley Hoffmann

"Hoffmann addresses the hardest issues in international politics with a wonderful combination of skeptical realism and moral commitment. The result is a challenging piece of political theory - and also (what most political theory isn't) a guide to statesmen."

Michael Walzer, Princeton University

Can moral behavior exist in a world of states? Under what conditions? Where do norms for moral behavior, considerations of right and wrong, fit in the relations between states?

Drawing upon many historical examples, Stanley Hoffmann examines three of the most burning contemporary issues as they relate to international politics: the case of moral restraints on the use of force, human rights, and the problems of distributive justice. Duties Beyond Borders suggests a course of ethical politics based on a pragmatic, realistic approach to international politics.

288 pages

Cloth $\$ 18.00$

Paper \$ 9.95

Af SYRACUSE UNIVERSITY PRESS Dept. A4

SUU 1011 East Water Street Syracuse, NY 13210

\section{Publications from the United Nations}

\section{United Nations Juridical Yearbook 1978}

Reviews the legal status of the United Nations and related intergovernmental organizations through the existing legislative texts and treaty provisions, including legal activities, judgements and advisory opinions. Current and tecent judicial decisions of international and national tribunats are contained in the Yearbook, and it is fully indexed with a legal bibliography.

Sales No. E.80.V.1 \$20.00

United Nations

Room A-3315

New York, N.Y. 10017

\section{Publications}

Palais des Nations

1211 Geneva 10, Switzerland 


\section{International Organization}

Volume 35, Number 3, Summer 1981

\section{Articles}

Third World indebted industrialization:

Jeff Frieden

international finance and state

capitalism in Mexico, Brazil, Algeria, and South Korea

Whither post-Mao

Samuel S. Kim

Chinese global policy?

Britain, the European Community,

Vincent A. Mahler

and the developing Commonwealth:

dependence, interdependence, and

the political economy of sugar

World shipping, UNCTAD,

Lawrence Juda and the New International

Economic Order

\section{Review essays}

Sovereignty at Bay

Raymond Vernon

ten years after

Social science

John F. McCamant

and

human rights

\section{Comments}

Measuring interdependence:

Richard Rosecrance and

a rejoinder William Gutowitz

Measuring interdependence:

Mary Ann Tetreault

a response 